\title{
Distribution of Plasma-membrane Fragments during Zonal Centrifugations of Homogenates from Aerobic Saccharomyces cerevisiae
}

\author{
By T. NURMINEN, L. TASKINEN AND H. SUOMALAINEN \\ Research Laboratories of the State Alcohol Monopoly (Alko), \\ Box 350, SF-oo Iо I Helsinki 10, Finland
}

(Received I7 May 1976; revised 24 August 1976)

\begin{abstract}
INTRODUCTION
During zonal centrifugations of homogenates from glucose-repressed Saccharomyces cerevisiae, the buoyant densities of various plasma-membrane fragments greatly depend on their content of heavy glycoprotein particles (Nurminen, Taskinen \& Suomalainen, 1976). Experiments with homogenates from aerobic $S$. cerevisiae are described here. A complicating factor in the isolation of the yeast plasma membrane is that the only marker enzyme known for it, $\mathrm{Mg}^{2+}$-dependent adenosine triphosphatase (Mg-ATPase), is also present in mitochondria. The mitochondrial Mg-ATPase, however, differs from the Mg-ATPase of the plasma membrane in being oligomycin-sensitive. In aerobic yeast, fully developed mitochondria are readily detectable in electron micrographs and the activity of the typical mitochondrial enzymes is high. Therefore the possible presence of mitochondrial membranes in the preparations of plasma membranes is easier to detect than in the glucose-repressed yeast.
\end{abstract}

\section{METHODS}

Organism. This was commercial baker's yeast (Saccharomyces cerevisiae), from the Rajamäki Factories of the Finnish State Alcohol Monopoly (Alko).

Preparation of subcellular fractions. Fresh cells were disrupted in a Mini-mill disintegrator, high-speed zonal centrifugations were performed in a B XV zonal rotor, and several of the membrane fractions obtained by zonal centrifugation on buffered sucrose were further fractionated on gradients of iso-osmotic Urografin as described previously (Nurminen et al., 1976).

Biochemical determinations. Enzyme assay procedures and analytical methods were as described by Nurminen et al. (1976).

Electron microscopy. Electron micrographs were obtained as described by Nurminen et al. (1976).

\section{RESULTS AND DISCUSSION}

Content of marker components in whole homogenates

The contents of the marker components in the whole homogenates 'have been reported (Nurminen et al., 1976, Table I), apart from the total carbohydrate which was $103 \mathrm{mg}$ (100 $\mathrm{mg}$ homogenate protein $)^{-1}$. 


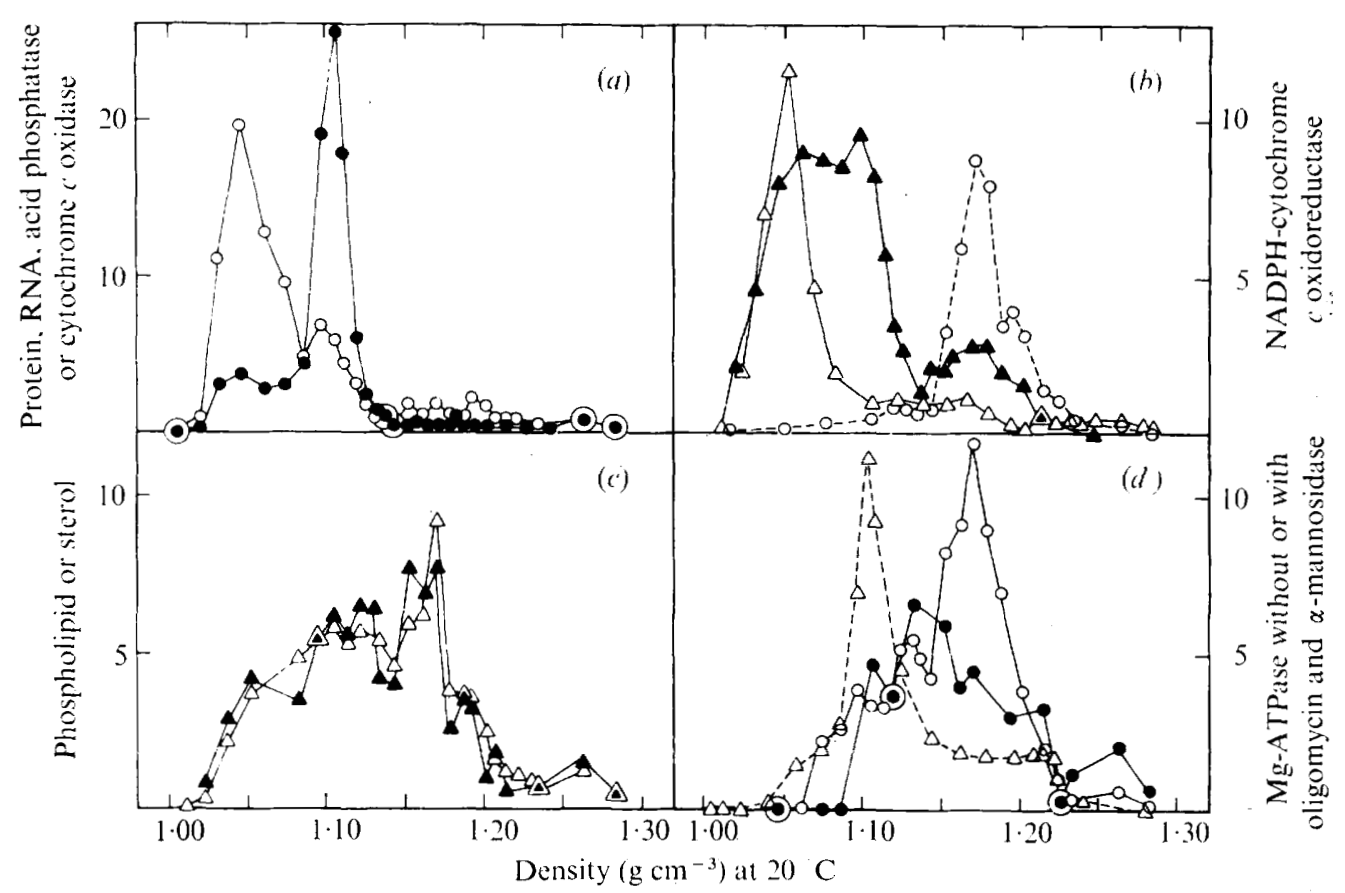

Fig. I. Fractionation of a whole homogenate of aerobic baker's yeast (S. cerevisae) by high-speed zonal centrifugation in a gradient of buffered sucrose. Centrifugation was at $20000 \mathrm{rev} . \mathrm{min}^{-1}$ for $360 \mathrm{~min}$ in a B XV rotor (approx. $5 \times 10^{6} \mathrm{~g}$-min at the sample zone). The density distributions of the following components are shown: $(a)$ protein $(\bigcirc)$ and RNA (O); $(b)$ acid phosphatase $(\triangle)$, NADPH-cytochrome $c$ oxidoreductase $(\Delta)$ and cytochrome $c$ oxidase $(\bigcirc) ;(c)$ phospholipid $(\triangle)$ and sterol $(\boldsymbol{\Delta}) ;(d) \alpha$-mannosidase $(\triangle)$ and $\mathrm{Mg}$-ATPase with $(\boldsymbol{O})$ and without $(\bigcirc)$ oligomycin. Results are expressed as percentages of the total amounts recovered in the density range I.00 to $\mathrm{I} \cdot 29 \mathrm{~g} \mathrm{~cm}^{-3}$.

Fractionation by high-speed zonal centrifugation in a Ficoll gradient

In buffered iso-osmotic Ficoll, about $75 \%$ of the protein was distributed at the densities $\mathrm{I} \cdot 04$ to $\mathrm{I} \cdot 08\left(\mathrm{~g} \mathrm{~cm}^{-3}\right)$, as was most of the alkaline pyrophosphatase $(98 \%)$, AMPase $(94 \%)$, alkaline phosphatase $(88 \%)$ and $\beta$-fructofuranosidase $(80 \%)$. The RNA showed only one maximum, at $\rho=\mathrm{I} \cdot 08$, whereas phospholipid and sterol distributed in a broad band at $\rho=\mathrm{I} \cdot 04$ to $\mathrm{I} \cdot \mathrm{IO}$, with two minor peaks at $\rho=\mathrm{I} \cdot \mathrm{I} 2$ to $\mathrm{I} \cdot \mathrm{I} 3$ and $\rho=\mathrm{I} \cdot \mathrm{I} 6$. NADPHcytochrome $c$ oxidoreductase was largely non-sedimentable, but did have a high activity coincident with the peak of the mitochondrial marker, cytochrome $c$ oxidase, and with the main peak of oligomycin-sensitive Mg-ATPase at $\rho=\mathrm{r} \cdot 08$ to $\mathrm{I} \cdot \mathrm{I} 0$.

The proportion of Mg-ATPase that was oligomycin-insensitive was about $15 \%$ around $\rho=\mathrm{I} \cdot 08,30$ to $40 \%$ at $\rho=\mathrm{I} \cdot 09$ to I.II, and about $70 \%$ at $\rho=\mathrm{I} \cdot \mathrm{I} 2$ to I.I 3 and above. Electron microscopy showed that smooth-surfaced, triple-layered membranes were the dominant objects at around $\rho=\mathrm{I} \cdot \mathrm{I} 2$. These membranes were evidently fragments of the plasma membrane, for this material contained oligomycin-insensitive Mg-ATPase.

\section{Fractionation by high-speed zonal centrifugation in a sucrose gradient}

After zonal centrifugation in sucrose gradients, about $65 \%$ of the protein, including most of the alkaline pyrophosphatase $(96 \%), \beta$-fructofuranosidase $(94 \%)$, alkaline phosphat- 
Table I. Chemical composition of the membrane fractions, and their oligomycin-insensitive $M g$-ATPase and cytochrome $c$ oxidase activities

Fractions SI to S6 were isolated at the specified densities by high-speed zonal centrifugation in sucrose gradients. They were further purified by swing-out centrifugation on Urografin gradients. The chemical compositions [ $\mu \mathrm{g}\left(\mathrm{mg}\right.$ protein) ${ }^{-1}$ ], the oligomycin-insensitivity of $\mathrm{Mg}$-ATPase [(units with oligomycin/units without oligomycin) $\times$ I00] and the specific activity of cytochrome $c$ oxidase

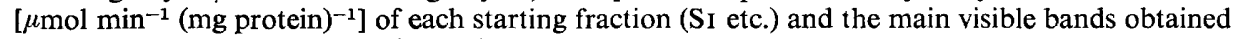
from it on Urografin (Ura etc.) are shown.

\begin{tabular}{|c|c|c|c|c|c|c|c|c|c|}
\hline 胥 & 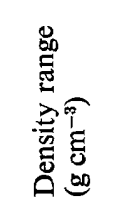 & $\underset{Z}{Z}$ & 艺 & 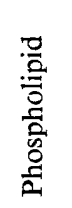 & $\begin{array}{l}\overrightarrow{0} \\
\vec{D} \\
\dot{n}\end{array}$ & 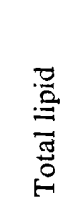 & 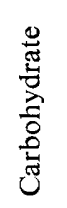 & 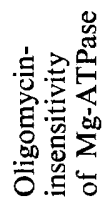 & 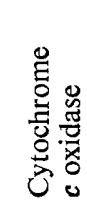 \\
\hline $\begin{array}{l}\text { Si } \\
\text { UIa } \\
\text { UIb }\end{array}$ & $\begin{array}{l}I \cdot 09-I \cdot I 3 \\
I \cdot I I-I \cdot I 6 \\
I \cdot I 7-1 \cdot 23\end{array}$ & $\begin{array}{r}350 \\
60 \\
20\end{array}$ & $\begin{array}{l}3 \\
1 \\
1\end{array}$ & $\begin{array}{l}130 \\
340 \\
280\end{array}$ & $\begin{array}{r}30 \\
30 \\
100\end{array}$ & $\begin{array}{r}380 \\
1460 \\
1080\end{array}$ & $\begin{array}{l}99 \\
74 \\
56\end{array}$ & $\begin{array}{l}18 \\
38 \\
75\end{array}$ & $\begin{array}{c}0.098 \\
\text { ND } \\
\text { ND }\end{array}$ \\
\hline $\begin{array}{l}\mathrm{S}_{2} \\
\mathrm{U}_{2}\end{array}$ & $\begin{array}{l}I \cdot I 6-I \cdot I 7 \\
I \cdot I 5-I \cdot I 9\end{array}$ & $\begin{array}{l}60 \\
30\end{array}$ & $\begin{array}{l}8 \\
4\end{array}$ & $\begin{array}{l}270 \\
250\end{array}$ & $\begin{array}{l}50 \\
60\end{array}$ & $\begin{array}{l}\text { ND } \\
750\end{array}$ & $\begin{array}{l}68 \\
70\end{array}$ & $\begin{array}{l}\text { I4 } \\
48\end{array}$ & $\begin{array}{c}2.009 \\
\text { ND }\end{array}$ \\
\hline $\begin{array}{l}\mathrm{S}_{3} \\
\mathrm{U}_{3}\end{array}$ & $\begin{array}{l}I \cdot I 8-I \cdot I 9 \\
I \cdot I 5-I \cdot I 9\end{array}$ & $\begin{array}{l}60 \\
10\end{array}$ & $\begin{array}{r}\mathrm{I} 2 \\
6\end{array}$ & $\begin{array}{l}280 \\
210\end{array}$ & $\begin{array}{l}40 \\
30\end{array}$ & $\begin{array}{l}\mathrm{ND} \\
780\end{array}$ & $\begin{array}{l}8 I \\
43\end{array}$ & $\begin{array}{l}20 \\
\text { ND }\end{array}$ & $\begin{array}{c}I \cdot 765 \\
\text { ND }\end{array}$ \\
\hline $\begin{array}{l}\mathrm{S}_{4} \\
\mathrm{U}_{4}\end{array}$ & $\begin{array}{l}I \cdot 2 I-I \cdot 22 \\
I \cdot I 5-I \cdot I 9\end{array}$ & $\begin{array}{l}50 \\
60\end{array}$ & $\begin{array}{r}\text { IO } \\
4\end{array}$ & $\begin{array}{l}\text { I } 10 \\
230\end{array}$ & $\begin{array}{l}20 \\
30\end{array}$ & $\begin{array}{l}\text { ND } \\
\text { ND }\end{array}$ & $\begin{array}{l}278 \\
823\end{array}$ & $\begin{array}{l}38 \\
89\end{array}$ & $\begin{array}{c}0.613 \\
\text { ND }\end{array}$ \\
\hline $\begin{array}{l}\mathrm{S}_{5} \\
\mathrm{U}_{5}\end{array}$ & $\begin{array}{l}I \cdot 23-I \cdot 24 \\
I \cdot I 5-I \cdot I 9\end{array}$ & $\begin{array}{l}90 \\
30\end{array}$ & $\begin{array}{r}\mathrm{I} 2 \\
8\end{array}$ & $\begin{array}{r}100 \\
50\end{array}$ & $\begin{array}{l}30 \\
40\end{array}$ & $\begin{array}{l}\text { ND } \\
\text { ND }\end{array}$ & $\begin{array}{l}253 \\
510\end{array}$ & $\begin{array}{r}87 \\
\text { ND }\end{array}$ & $\begin{array}{c}0.345 \\
\text { ND }\end{array}$ \\
\hline $\begin{array}{l}\text { S6 } \\
\text { U6 }\end{array}$ & $\begin{array}{l}I \cdot 25-I \cdot 27 \\
I \cdot 19-I \cdot 23\end{array}$ & $\begin{array}{r}140 \\
60\end{array}$ & $\begin{array}{l}3 \\
I\end{array}$ & $\begin{array}{l}150 \\
190\end{array}$ & $\begin{array}{l}50 \\
40\end{array}$ & $\begin{array}{l}\text { ND } \\
1080\end{array}$ & $\begin{array}{l}484 \\
680\end{array}$ & $\begin{array}{l}87 \\
8 \mathrm{I}\end{array}$ & $\begin{array}{c}0.168 \\
\text { ND }\end{array}$ \\
\hline
\end{tabular}

ND, Not determined

ase $(85 \%)$, acid phosphatase $(67 \%)$ and AMPase $(6 \mathrm{I} \%$ ), was at $\rho=\mathrm{I} \cdot 03$ to $\mathrm{I} \cdot 06$ (Fig. I). About $65 \%$ of the RNA was coincident with the second protein peak at $\rho=\mathrm{I} \cdot \mathrm{IO}$. The fractions around $\rho=\mathrm{I} \cdot \mathrm{IO}$ were rich in mixed light membranes, including membranes of the rough endoplasmic reticulum (the main peaks of RNA and NADPH-cytochrome $c$ oxidoreductase), vacuolar membranes (the maximum of $\alpha$-mannosidase, the marker for vacuolar membranes; van der Wilden et al., 1973), and membranes containing Mg-ATPase. The main peaks of cytochrome $c$ oxidase (about $70 \%$ ) and oligomycin-sensitive Mg-ATPase indicate the presence of mitochondria at $\rho=I \cdot I 6$ to $I \cdot I 8$. Electron microscopy also showed mitochondria to be the dominant organelles in this density range.

About $20 \%$ of the phospholipid and $40 \%$ of the sterol were non-sedimentable $(\rho<\mathrm{I} \cdot 09)$. Their peaks above $\rho=\mathrm{I} .09$ indicate the positions of the major part of the membrane material. Less than $10 \%$ of Mg-ATPase was non-sedimentable, but otherwise its distribution resembled that of phospholipid and sterol. The proportion of oligomycin-insensitive Mg-ATPase increased towards the higher densities (Table I), and was 80 to $100 \%$ at $\rho=\mathrm{I} \cdot 23$ to $\mathrm{I} \cdot 26$.

Electron micrographs of the material present in the last peak of phospholipid and sterol at $\rho=\mathrm{I} \cdot 26$ revealed smooth-surfaced, triple-layered single-unit membranes as the dominant objects. Because its Mg-ATPase was nearly completely oligomycin-insensitive and practically no NADPH-cytochrome $c$ oxidoreductase or cytochrome $c$ oxidase was present, it is reasonable to conclude that these membranes were heavy fragments of plasma membrane. 


\section{Subfractionation of zonal fractions on a Urografin gradient}

Fraction SI (Table I) was rich in light membranes. Sedimentation through Urografin increased its total lipid, phospholipid and sterol contents and decreased its RNA, DNA and protein contents. The removal of rough endoplasmic reticulum was indicated by the marked decrease in RNA. The proportion of oligomycin-insensitive Mg-ATPase increased to $75 \%$ in fraction UIb. This suggests that an enrichment of the light vesicles of the plasma membrane was obtained. The presence of vacuolar membranes is unlikely, for these move slowly even through a flat Urografin gradient (van der Wilden et al., 1973).

$\mathrm{S}_{2}$ and $\mathrm{S}_{3}$ were mitochondrial fractions as indicated by their high specific activity of cytochrome $c$ oxidase. The proportion of carbohydrate in fractions $\mathrm{S}_{4}, \mathrm{~S}_{5}$ and $\mathrm{S} 6$ was markedly higher than in the less dense fractions, $S_{1}, S_{2}$ and $S_{3}$, and was further increased after purification on Urografin. The decrease in the specific activity of cytochrome $c$ oxidase indicated that the amount of mitochondria in these fractions decreased towards the higher densities. Fraction U6 is representative of the purity of the plasma membrane preparations achieved in this work.

Fractions SI, S4, S5 and S6 contained mannose as the dominant sugar; in each fraction it formed about $60 \%$ of the total amount of hexoses and inositol. A high content of mannose is a characteristic of yeast plasma membrane preparations isolated by mechanical means (Matile, Moor \& Mühlethaler, 1967; Matile, 1970; Fuhrmann, Wehrli \& Boehm, 1974; Nurminen et al., 1976). Matile et al. (1967) found mannose as the only hexose in their preparation and showed that the globular particles of the plasma membrane are composed of mannanprotein. In addition to mannose, fractions $\mathrm{Sr}_{1}, \mathrm{~S}_{4}, \mathrm{~S}_{5}$ and $\mathrm{S} 6$ contained glucose, galactose and inositol. A certain amount of the three hexoses and inositol in our preparations can be attributed to the plasma membrane glycolipids (cf. Nurminen \& Suomalainen, 197I ; Työrinoja, Nurminen and Suomalainen, 1974). Most of the inositol in the plasma membrane is present as phosphatidylinositol. The proportion of mannose in fractions $\mathrm{S}_{4}, \mathrm{~S}_{5}$ and S6 was similar to that in the heavy membranes isolated from glucose-repressed cells (Nurminen et al., 1976). However, the total carbohydrate was considerably lower in the three aerobic fractions than in the preparation isolated at $\rho=\mathrm{I} \cdot 24$ to $\mathrm{I} \cdot 26$ from glucose-repressed yeast. These observations suggest that the heavy mannanprotein particles are largely responsible for the high density of the plasma-membrane fragments, but they are detached more easily from the plasma membrane of aerobic yeast. Alternatively, there may be fewer of these particles in the resting aerobic cells than in the budding glucose-repressed cells in which the particles may carry material for the new cell wall.

\section{REFERENCES}

FuhrmanN, C. F., Wehrli, E. \& Boehm, C. (I974). Preparation and identification of yeast plasma membrane vesicles. Biochimica et biophysica acta 363, 295-310.

Matile, Ph. (1970). Properties of the purified cytoplasmic membrane of yeast. In Membrane Structure and Function. Federation of European Biochemical Societies, 6th Meeting, Madrid 1969, pp. 39-49. Edited by J. R. Villanueva and F. Ponz. London and New York: Academic Press.

Matile, Ph., MoOR, H. \& Mühlethaler, K. (I967). Isolation and properties of the plasmalemma in yeast. Archiv für Mikrobiologie 58, 20I-2II.

Nurminen, T. \& Suomalainen, H. (I97I). Occurrence of long-chain fatty acids and glycolipids in the cell envelope fractions of baker's yeast. Biochemical Journal 125, 963-969.

Nurminen, T., Taskinen, L. \& Suomalainen, H. (1976). Distribution of membranes, especially of plasmamembrane fragments, during zonal centrifugations of homogenates from glucose-repressed Saccharomyces cerevisiae. Biochemical Journal 154, 75I-763.

Työrinoja, K., Nurminen, T. \& SuOmalainen, H. (1974). The cell-envelope glycolipids of baker's yeast. Biochemical Journal r4r, I33-139.

Wilden, W. van der, Matile, Ph., Schellenberg, M., Meyer, J. \& Wiemken, A. (I973). Vacuolar membranes: isolation from yeast cells. Zeitschrift für Naturforschung, Teil C 28, 416-42I. 